\title{
Endometriosis of the rectosigmoid colon mimicking gastrointestinal stromal tumor
}

\author{
Mehmet Tolga Kafadar' ${ }^{1}(\mathbb{D})$, Tuğba Çaviş ${ }^{2}(\mathbb{D})$, Önder Sürgit ${ }^{3}(\mathbb{D})$, Aslı Köktener ${ }^{4}(\mathbb{D}$ \\ ${ }^{1}$ Clinic of General Surgery, Mehmet Akif İnan Training and Research Hospital, Şanlıurfa, Turkey \\ ${ }^{2}$ Clinic of Radiology, Atatürk Training and Research Hospital, Ankara, Turkey \\ ${ }^{3}$ Clinic of General Surgery, Medicana International Ankara Hospital, Ankara, Turkey \\ ${ }^{4}$ Clinic of Radiology, Ankara Umut Hospital, Ankara, Turkey
}

\begin{abstract}
Endometriosis is defined as the growth of functional endometriotic gland and stroma outside the uterine cavity. Although it is common in women of reproductive age, extragenital endometriosis is considerably rare. Due to its frequent localization at the rectosigmoid junction in the gastrointestinal system, endometriosis may manifest with abdominal pain, constipation, and rectal bleeding. Gastrointestinal stromal tumor is the most common mesenchymal tumor of the gastrointestinal system and develops from the muscularis propria. Its extraluminal component is prominent. This study aimed to report a rare case of a 37-year-old patient who was operated with laparoscopic colon resection for a malignant-appearing submucosal mass with indistinct borders at the rectosigmoid junction that received the final diagnosis in histopathological examination. Endometriosis should be considered in the differential diagnosis of non-specific gastrointestinal symptoms in female subjects of reproductive age as the one reported here.
\end{abstract}

Keywords: Endometriosis, rectosigmoid, malignancy, laparoscopic resection

Cite this article as: Kafadar MT, Çaviş T, Sürgit Ö, Köktener A. Endometriosis of the rectosigmoid colon mimicking gastrointestinal stromal tumor. Turk J Surg 2020; 36 (4): 409-412

Corresponding Author Mehmet Tolga Kafadar E-mail: drtolgakafadar@hotmail.com

Received: 22.11.2016

Accepted: 31.01 .2017

Available Online Date: 29.12 .2020

o Copyright 2020 by Turkish Surgical Society Available online at www.turkjsurg.com

DOI: $10.47717 /$ turkjsurg. 2020.3730

\section{INTRODUCTION}

Endometriosis is defined as the presence of endometrial glands and stroma outside the uterine cavity (1). Its prevalence among women of reproductive age is 15\% and $50 \%$ among infertile women. The diagnosis of extrapelvic endometriosis is challenging, and clinicians usually fail to consider it in differential diagnosis owing to variable symptoms depending on the site of localization. Despite its characteristic pathological appearance independent of its localization, it may be radiologically confused with tumors originating from tissues it is located (2). This study aimed to report a case of endometriosis that mimicked a gastrointestinal stromal tumor (GIST) in the rectosigmoid region.

\section{CASE REPORT}

A 37-year-old nulliparous woman presented to the obstetrics and gynecology outpatient clinic with pelvic pain and abdominal bloating for 2 days. Her history was not remarkable for any chronic disorder, regular use of medications, or previous surgery. On physical examination, she had tenderness upon palpation, guarding, and rebound in the left lower quadrant and suprapubic region. Rectal examination revealed no palpable mass. Laboratory findings indicated leukocytosis, and elevated CRP and CA-125 levels; other laboratory results were normal. She underwent a transvaginal ultrasonography for an initially suspected ovarian cyst rupture or pelvic abscess, which showed a hypoechoic lesion located adjacent to the left ovary that had a diameter of $3 \mathrm{~cm}$ with a dense content. In order to rule out a hemorrhagic cyst or abscess formation, a multislice computed tomography (CT) was obtained, which demonstrated a mass lesion with a size of $4 \times 3.5 \mathrm{~cm}$ in the rectosigmoid region. The mass was indiscernible from the intestinal wall; it was mildly enhanced by I.V. contrast agent; and it caused no obstruction (Figure 1). The lesion was initially considered to be a GIST or an endometriotic lesion. A subsequent rectosigmoidoscopic examination showed a submucosal mass in the rectosigmoid region. With these findings, the patient was taken to the operating theater to be operated jointly with the Obstetrics and Gynecology department. Upon exploration, a firm mass 


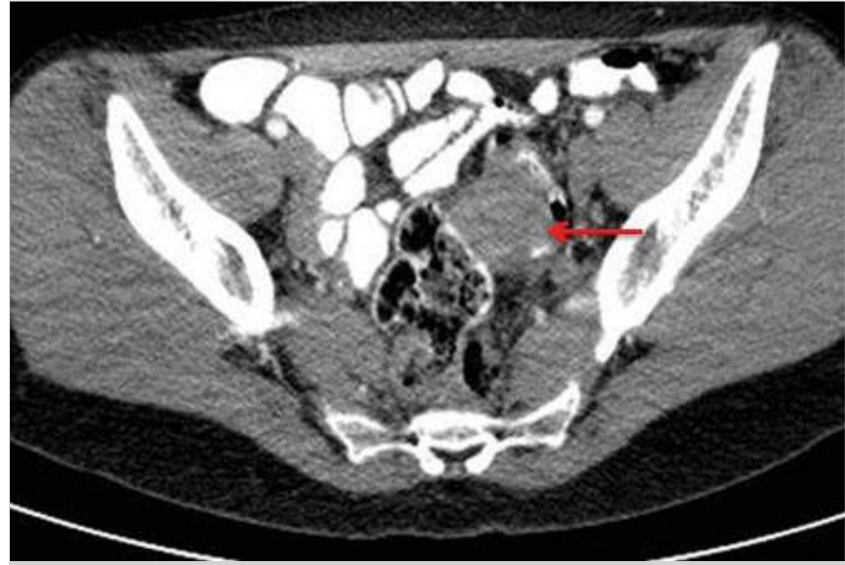

Figure 1. Axial contrast-enhanced CT shows a mass lesion in the rectosigmoid region. The mass is indiscernible from intestinal wall, it is mildly enhanced by I.V. contrast agent, and it causes no obstruction.

with irregular borders was spotted in the rectosigmoid junction, which was suspected for a malignancy, and frozen examination was done and the diagnosis of endometriosis was confirmed. Laparoscopic anterior resection + end-to-end anastomosis using staplers were performed. No postoperative complication was observed, and the patient was discharged with full recovery on the postoperative seventh day. The definitive histopathological diagnosis of the patient was reported to be foci of endometriosis interspersed in-between the submucosa and muscularis propria muscle fibers in the rectosigmoid colon (Figure 2A, B).

\section{DISCUSSION}

The most accepted theory about the development of endometriosis is the retrograde extension theory put forth by Sampson, which theorizes the migration of endometrial cells into the peritoneal cavity and various other sites via Fallopian tubes during menstrual cycles (3). Endometriosis typically involves genital or- gans and pelvic peritoneum, but it also rarely affects the gastrointestinal system (GIS), lungs, mesentery, urinary bladder, greater omentum, surgical scars, skin, kidneys, and nasal cavity. In the GIS, it usually involves the rectosigmoid junction (74\%) followed by the ileum and appendix (4). Intestinal endometriosis is usually asymptomatic but may lead to gastrointestinal bleeding, abdominal cramps, nausea, vomiting, diarrhea, constipation, and intussusception. Symptoms alone are not diagnostic (5). Our patient had severe abdominal pain and bloating.

GIST is the most common mesenchymal tumor of the GIS. It originates from Cajal interstitial cells found in the myenteric plexus and smooth muscle cells of the GIS. It usually affects people older than 40 years of age. It may appear anywhere in the GIS, although it frequently involves the stomach (39-70\%) and small intestine (20-32\%) but also, albeit rarely, the colon, rectum (5\%), esophagus (2\%), and appendix. GIST is usually asymptomatic in its early stages. In advanced cases, it most commonly gives rise to abdominal pain (50-70\%), gastrointestinal bleeding (20-30\%), and a palpable abdominal mass. Its diagnosis is usually achieved by $C T$ and magnetic resonance imaging (MRI). In addition, a submucosal mass may be revealed by GIST endoscopy or colonoscopy, a regular-border filling defect by double contrast colonic $X$-Ray, or a hypoechoic lesion originating from muscularis propria by endoscopic ultrasonography (6).

Endometriosis usually involves serosa or subserosa although it may involve all layers of the colon simultaneously. It may rarely appear as a nodular mass infiltrating the intestinal wall. In the presence of a deep invasion by lesions, it may falsely be interpreted as colon cancer, Crohn's disease, or carcinoid tumor. Furthermore, it may incite inflammation and fibrosis within the intestines, leading to luminal narrowing and obstruction in time. As a result, intestinal obstruction and perforation may occur (7).
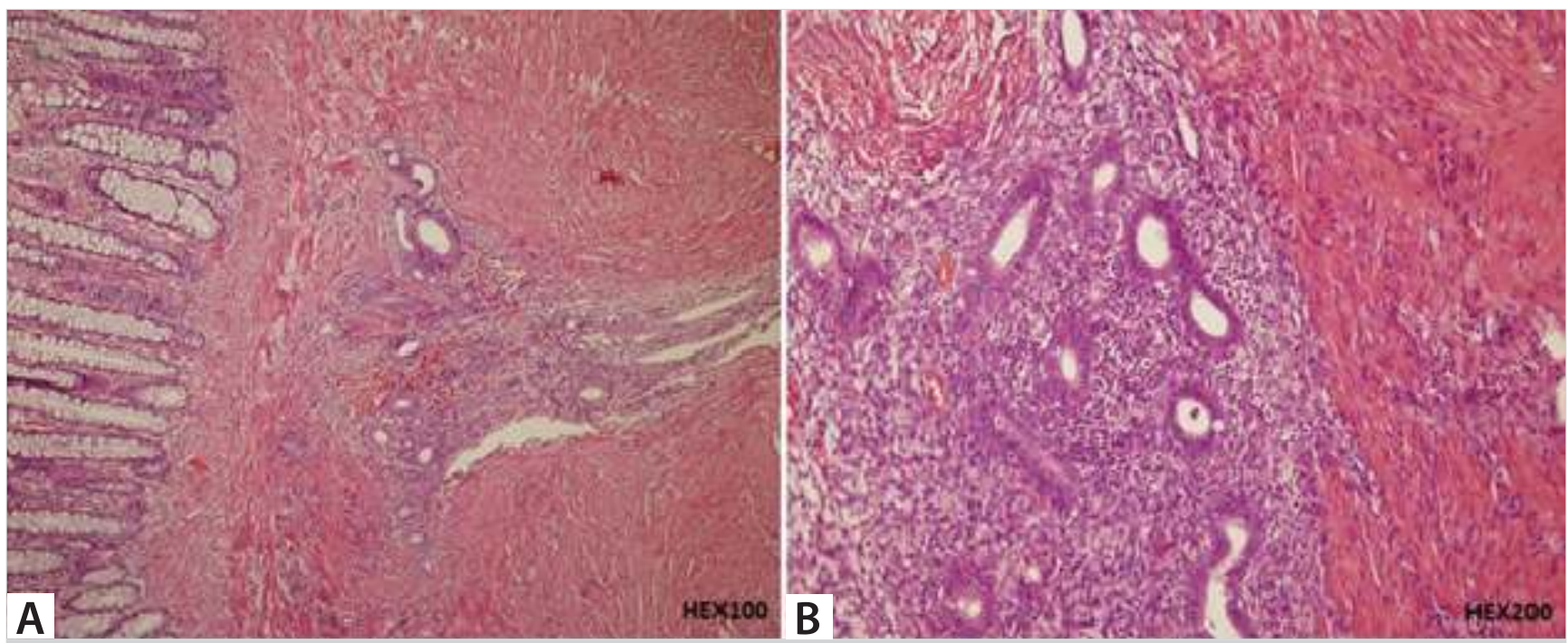

Figure 2. A.B Endometrial stroma and endometrial glands between submucosa and muscle fibers of muscularis propria (HEX100, HEX200). 
As for GIST, diagnosis can be achieved by ultrasonography, CT, $\mathrm{MRI}$, and colonoscopy, depending on the localization of the lesion. Although radiological imaging techniques cannot always provide a definitive diagnosis, they can still inform about the lesion's size, localization, and depth. Submucosal mass lesions protruding into the lumen and covered by normal mucosa seen in colonoscopy may be of intramural or extramural origin. Lipoma, lymphangioma, carcinoid tumor, GIST, and leiomyoma are examples of intramural lesions while peritoneal carcinomatosis, extracolonic tumor invasions are examples of extramural neoplasms. Non-neoplastic intramural lesions include lymphoid hyperplasia, hematoma, vascular lesions, pneumatosis cystoides coli, while extramural lesions include endometriosis (8). Since the clinical presentation of patients with intestinal endometriosis may be confused with many disorders including malignant conditions, diagnosis may be delayed and difficult. Fine needle biopsy is helpful for making the diagnosis although surgery and histopathological examination of the surgical excision material are usually required for a definitive diagnosis and to rule out a malignancy. Most intestinal endometriosis cases are diagnosed at laparoscopy or laparotomy (9). Our case could similarly not be diagnosed in the preoperative phase. Despite the lesion's resemblance to a GIST for its rectosigmoid involvement pattern, tomographic findings, and rectosigmoidoscopic appearance, it received a definitive diagnosis after the pathological examination of the laparoscopically excised lesion from the rectosigmoid junction.

Various hormone suppression therapies previously applied for intestinal endometriosis usually proved unhelpful. Patients who cannot be operated for any reason can be medically managed by non-steroidal anti-inflammatory drugs, danazol, gonadotropin-releasing hormone and oral contraceptives. The majority of patients with this condition display significant improvement although recurrences are common when therapy is stopped. Hence, surgery should particularly be the first option in younger patients and those with severe symptoms. Resection of the affected intestinal segment and re-anastomosis of the intact parts is the best accepted approach for intestinal endometriosis. Recurrence rates remain low after total excision (10).

\section{CONCLUSION}

In women of reproductive age, intestinal endometriosis, even if asymptomatic, should be included in the differential diagnosis of submucosal lesions of the rectosigmoid colon in addition to
GISTs and carcinoid tumors. This rare condition may mimic many other disorders. Definitive diagnosis is only possible through surgical resection and histopathological examination of the lesions.

Informed Consent: Informed consent was obtained from patient who participated in this case.

Peer-review: Externally peer-reviewed.

Author Contributions: Concept - M.T.K., T.Ç., A.K.; Design - M.T.K., Ö.S., A.K.; Supervision - M.T.K., T.Ç., Ö.S.; Resource - M.T.K., T.Ç., A.K.; Materials - M.T.K., T.Ç., Ö.S.; Data Collection and/or Processing - M.T.K., A.K.; Analysis and/or Interpretation - M.T.K., A.K.; Literature Search - M.T.K., T.Ç.; Writing Manuscript - M.T.K., A.K.; Critical Reviews - M.T.K., Ö.S., A.K.

Conflict of Interest: No conflict of interest was declared by the authors.

Financial Disclosure: The authors declared that this study has received no financial support.

\section{REFERENCES}

1. Spaczynski RZ, Duleba AJ. Diagnosis of endometriosis. Semin Reprod Med 2003; 21: 193-208. [CrossRef]

2. Eskenazi B, WarnerML. Epidemiology of endometriosis. Obstet Gynecol Clin North Am 1997; 24: 235-58. [CrossRef]

3. Nezhat F, Shamshirsaz A, Yildirim G, Nezhat C. Pelvic pain, endometriosis, and the role of the gynecologist. In: Altcheck A and Deligdisch L (eds.). Pediatric, Adolescent and Young Adult Gynecology. $1^{\text {st }} \mathrm{ed}$. New Jersey: Wiley-Blackwell, 2009: 174-94. [CrossRef]

4. Remorgida V, Ferrero S, Fulcheri E, Ragni N, Martin DC. Bowel endometriosis: presentation, diagnosis and treatment. Obst Gynecol Surv 2007; 62: 461-70. [CrossRef]

5. Bartkowiak R, Zieniewicz K, Kaminski P, Krawczyk M, Marianowski L, Szymanska K. Diagnosis and treatment of sigmoidal endometriosis-a case report. Med Sci Monit 2000; 6: 787-90. [CrossRef]

6. Sturgeon C, Chejfec G, Espat NJ. Gastrointestinal stromal tumors: a spectrum of diseases. Surg Oncol 2003; 12:21-6. [CrossRef]

7. Yıldırım S, Nursal TZ, Tarım A, Torer N, Bal N, Yıldırım T. Colonic obstruction due to rectal endometriosis: report of a case. Turk J Gastroenterol 2005; 16: 48-51. [CrossRef]

8. Sassi S, Bouassida M, Touinsi H, Mighri MM, Baccari S, Chebbi F, et al. Exceptional cause of bowel obstruction: rectal endometriosis mimicking carcinoma of rectum- a case report. Pan African Medical Journal 2011; 10: 33. [CrossRef]

9. Erkan N, Haciyanli M, Sayhan H. Abdominal wall endometriomas. Int J Gynaecol Obstet 2005; 89: 59-60. [CrossRef]

10. Verspyck E, Lefranc JP, Guyard B, Blondon J. Treatment of bowel endometriosis: A report of six cases of colorectal endometriosis and a survey of the literature. Eur J Obstet Gynecol Reprod Biol 1997; 71: 81-4. [CrossRef] 


\section{OLGU SUNUMU-ÖZET}

Turk J Surg 2020; 36 (4): 409-412

\section{Gastrointestinal stromal tümörü taklit eden rektosigmoid kolon endometriyozis}

Mehmet Tolga Kafadar ${ }^{1}$, Tuğba Çavişร ${ }^{2}$, Önder Sürgit ${ }^{3}$, Aslı Köktener ${ }^{4}$

'Mehmet Akif İnan Eğitim ve Araştırma Hastanesi, Genel Cerrahi Kliniği, Şanlıurfa, Türkiye

${ }^{2}$ Atatürk Eğitim ve Araştırma Hastanesi, Radyoloji Kliniği, Ankara, Türkiye

${ }^{3}$ Medicana International Ankara Hastanesi, Genel Cerrahi Kliniği, Ankara, Türkiye

${ }^{4}$ Ankara Umut Hastanesi, Radyoloji Kliniği, Ankara, Türkiye

\section{ÖZET}

Endometriyozis, fonksiyonel endometriyotik gland ve stromanın uterin kavite dışında büyümesi olarak tanımlanır. Ekstragenital endometriyozis oldukça nadir görülen bir hastalık olmakla birlikte, doğurganlık çağındaki kadınlarda daha yaygın görülür. Gastrointestinal sistemde en sık rektosigmoid bileşkede görülen endometriyozis; karın ağrısı, konstipasyon, rektal kanama gibi semptomlara neden olabilir. Gastrointestinal stromal tümör, gastrointestinal sistemin en sık görülen mezenkimal tümörüdür ve muskularis propriadan gelişir. Ekstraluminal komponenti belirgindir. Bu yazıda, rektosigmoid bileşkede sınırları net ayırt edilemeyen, malign görünümlü submukozal kitle nedeniyle laparoskopik kolon rezeksiyonu yapılan ve histopatolojik inceleme ile kesin tanı alan 37 yaşında, nadir bir olgu sunuldu. Olgumuzda olduğu gibi nonspesifik gastrointestinal semptomları olan üreme çağındaki kadın hastalarda, ayıııcı tanıda endometriyozis de düşünülmelidir.

Anahtar Kelimeler: Endometriyozis, rektosigmoid, malignite, laparoskopik rezeksiyon

Doi: $10.47717 /$ turkjsurg.2020.3730 